\title{
Rentierism and the commons: A critical contribution to Brett Christophers' Rentier Capitalism
}

\begin{abstract}
In recent years, we have seen an increasing number of publications that offer the term of rentierism to define the current economic system in the Global North. More recently, Brettt Christophers has produced a series of work that aims to account for the ascendancy of rentierism from a political-economy perspective -in which Marx is mostly neglected. This exchange article aims to bring Marx and Marxist thought back into discussion to read rentierism politically. In particular, it inquiries into how rentierism relates to the nature of class relations by addressing an "open secret", namely that rentierism rests essentially on the enclosure and expropriation of the commons. It analyses rentierism as capital's counter-movement, enforcing its priorities and drives on spaces where alternative social systems emerge and develop. In the final part, a provocative conclusive remark is offered on Christophers' "what is to be done?".
\end{abstract}

Keywords: autonomist Marxism, rentierisation, rentierism, rentier capitalism, the commons 


\section{Introduction}

In recent years, we have seen an increasing number of publications that offer the term of rentierism to characterise the current transformation of capitalism in the Global North (Askenazy, 2016; Mazzucato, 2018; Piketty, 2014; Sayer, 2015; Standing, 2016). One of the key arguments traversing these accounts is that since the late 1970s there has been a major shift towards a system of economic production and reproduction in which income generation has increasingly come to be a matter of possessing and controlling valuable assets that are scarce or artificially made scarce. This corresponds to a mode of economic organisation in which money-making rests increasingly on having rather than doing or extracting value rather than creating it.

More recently, Brett Christophers $(2019,2020)$ has offered 'a political-economic critique' of rentierism as a contribution to the cited literature which, according to the author, has approached the phenomenon either 'ideologically' (Askenazy and the recent work of Piketty, 2020) or in 'the tradition of "moral economy"' (Mazzucato, Sayer and Standing) (2020: xxviii-xxix). In this empirically grounded and elegantly articulated politicaleconomic critique, nevertheless, Marx is largely neglected. Christophers argues, 'Marx's rent was essentially everyone else's [e.g. Ricardo, Smith] rent' (2019: 4). In Marx, rent was a pre-capitalist category, that is, 'a marginal, residual or ephemeral phenomenon within capitalism' (Christophers, 2020: xxvi). This view leads Christophers to offer an early conclusion that 'the reality of the early twenty-first century [i.e. rentierism] clearly belies ... Marx' (2020: xxvii, emphasis added).

This argument is disputable (see Vercellone, 2008 i; also Harvey, 2014 ii, 2019 ii; Negri, 2018 iv). The aim of this short exchange article, nevertheless, is not to discuss to what extent the transformation of industrialism into rentierism was latently present in Marx's writings or to summarise how Marxist scholars early foresaw and theorised the return of rentierism precisely through Marx. Instead, it aims to bring Marx and (autonomist) Marxist thought back into discussion to read rentierism politically, that is, a strategic reading of rentierism from the perspective of class relations (Cleaver, 2000). Indeed, Christophers' analysis of rentier capitalism is largely confined to the realm of economics and its "reified" categories. Herein, the concept of capital(ism) seems to designate not the social relations between classes but rather a set of economic actors (mostly corporations) 
and economic parameters such as asset prices, investment volumes, productivity, growth rates ... 'all circulating as mindless entities through the ups and downs of [capital's] circuits' (Cleaver, 2000: 44). In brief, Christophers does not engage with the question of how rentierism 'relates to the nature of the class relations' (Cleaver, 2000: 76). This exchange article aims to address this question.

In the first part of this article, I will briefly summarise Christophers' account of rentier capitalism to make first-time readers acquainted with his ideas as well as to contextualise my contribution. This contribution is based on an "open secret", namely that rentierism rests essentially on the enclosure and expropriation of the commons. In the second part, I will discuss the political meaning (as understood above) of this truism through Marx and autonomist Marxist thought. In particular, I will analyse rentierism as a political project, that is, capital's counter-movement that enforces separation on spaces where communities organise on the terrain of commons, experiment with the processes of commoning and develop alternative ways of social (re)production that are increasingly outside the circuits of capital.

\section{Rentier Capitalism}

Defining rent as 'income derived from the ownership, possession or control of scarce assets and under conditions of limited or no competition' and rentiers as those whose income primarily comes from the control of these assets, Christophers identifies rentier capitalism as Western countries' contemporary 'economic system' that is 'substantially scaffolded by and organized around the assets that generate those rents and sustain those rentiers' (Christophers, 2020: xxiv, xviii) v. We have some qualifiers here.

Firstly, Christophers recognises that only a 'few [rent-bearing] assets, if any, generate income automatically', that is, rent income requires control of an asset under conditions of limited or no competition as well as some 'work for the delivery of the product or service underwritten it' (2020: xxv). Given the broad definition of rent, secondly, Christophers acknowledges that most economic production involves rentier elements. What is particular about rentier capitalism, in connection to the first point, is that of scale. It entails '[rent-bearing] assets being not just leveraged in production but substantively so' (Christophers, 2020: xxvi). Indeed, he shows that 'the leading corporations [in the UK] 
are largely rentiers; and the biggest sectors of the economy are largely characterised by rentier dynamics' (Christophers, 2019: 3). He remarkably puts that 'rent is their shared raison d'être, and rentierism is embedded in their individual and collective DNA' (Christophers, 2019: 21).

Thirdly, Christophers underlines that rentierism is not a novel phenomenon. We are now witnessing the return and ascendancy of it. He agrees with Arrighi (1994) and Piketty (2014) in that the rentierisation of the economy has been a cyclical phenomenon over the longue durée, punctuating international capitalist development on a recurring basis. The return of rentierism, according to Christophers, has taken shape over the course of the past four decades under neoliberal economic policies. How? He offers four key respects in which neoliberalism has had beneficial consequences for rentierism (2020: 24-28): i) a growing pool of valuable assets has been made available for capital owners through privatisation, financial deregulation, and so forth; ii) policies such as the neutralisation of competition have been activated, enabling asset owners to further exploit their assets commercially; iii) rentier-friendly monetary and fiscal policies such as tax subsidies have been created; and iv) asset prices have artificially been accelerated to promote rentierism and make rentiers more wealthy.

For Christophers, the return of rentierism has had several adverse consequences for the UK economy (2020: 29-48). His starting point is what he calls (Christophers, 2020: 29) 'the essence' of rentierism, namely monopoly power in the control and exploitation of rent-bearing assets: inimical to economic dynamism, innovation, and the development of production. By analysing the UK data, Christophers shows how the lack of motivation to innovate and advance the production process has gone hand in hand with the plunge of capital investment and labour productivity since the 1970s. The inevitable result has been declining growth in economic output, that is, a slowdown in the overall economy. The latter has then culminated in a major re-sorting of incomes in a way that the pain has been shouldered by workers, while capital has begun to enjoy a greater share of national income. In parallel, finally, wealth inequality has increased dramatically -a typical result of rentierism as discussed by Piketty (2014).

\section{Rentierism and the commons}


In this part, my objective is to read rentierism politically (Cleaver, 2000). It is based on an understanding of the concept of capital as a social relationship in which opposing forces confront each other. In this antagonistic relationship, capital acts as a force that is committed to a continuous expansion: 'accumulate, accumulate! That is Moses and the prophets! (Marx, 1990: 742). This commitment concerns not only growth in monetary terms but also the continuous accumulation of capital-relation: 'the capitalist process of production ... produces not only commodities, not only surplus-value, but it also produces and reproduces the capital-relation itself; on the one hand the capitalist, on the other the wage-labourer' (Marx, 1990: 724). What capital desires, in other words, is 'to create lifeworlds in its own-image or to colonise existing ones ... since the beginning of its history ... until it has colonised all of life' (De Angelis, 2004: 67).

Nevertheless, capital exists with other forces that act as limit on its 'sole drive to valorise itself' (Marx, 1990: 342, see Harvey, 2010: 40-58) vi. Marx identifies the major opposing social force as 'living labour as subjective being' (Marx, 1993: 461). The latter 'expresses an absolute interest [i.e. emancipation from capital], which cannot be mediated' (Zanini, 2010: 44, also Tronti, 1966). This interest manifests itself in political actions such as strikes, refusal of work, sabotage, slowdown, absenteeism, and so on. But it also manifests itself in more "radical" forms which include not only resistance but also reversal, such as the invention of alternative socio-economic systems that provide various degrees of protection from the relations of capitalism (see Parker et al., 2014). Confronted with this, capital creates and implements counter-strategies because it cannot abide limits: 'capital is the endless and limitless drive to go beyond its limiting barrier ... Every limit appears as a barrier to overcome' (Marx, 1993: 334, 408).

In defining rentierism as a socio-economic system in which incomes are substantially generated by rents, Christophers also provides an overview of the core asset types that are at the centre of this system (2019: 7-13). He identifies these assets as land, natural resources such as water (that also yields natural monopoly rents), intellectual property, electro-magnetic spectrum, user-generated data on digital platforms, and financial assets that often manifest themselves as the tradeable form of other rent-bearing assets (e.g. commodity markets, see Tricarico, 2012). What is notable here, in my opinion, is that all these assets that generate rents and sustain rentierism can fairly be understood as the commons. If rentierism designates a system of economic production and reproduction that 
dominantly characterises today's capitalism in the Global North, this system is based essentially on the enclosure and expropriation of the commons.

In the literature, the commons refer typically to a resource pool that contains 'all the creations of nature that we inherit jointly and freely, and hold in trust for future generations' (Hodkinson, 2010: 243). The air, water, rivers, land, forests, fruits of the soil, fisheries, electro-magnetic spectrum and so forth are the commonwealth of the material world. Yet, there is extensive Marxist literature that conceptualises the commons beyond the fruits of nature. Here, the commons are also understood as human-made resources (e.g. creative, cultural, social commons) whose creation is based on the accumulated general intellect (and affect) of humankind and, in many cases, are produced through the channels of social cooperation beyond the capital-relation (Bollier and Helfrich, 2012a, 2012b; Boutang, 2011; De Angelis, 2001; Fuchs, 2014; Hardt, 2010; Hardt and Negri, 2009; Holder and Flessas, 2008; Nonini, 2006; Shiva 2002). Indeed, according to Marx, products such as knowledge(s), languages, information, affects, ideas, and so forth are the creations of 'universal and communal labour', 'brought about partly by the cooperation of men now living, but partly also by building on earlier work' (1992: 199) vii. In this broader view, the commons are understood both as a noun and a verb. They refer not only to nature's gift and human-made communal resources, but also to the processes of production whereby these resources are allocated, used and (re)produced in a way that increasingly escapes the capital-relation (i.e. commoning, see Linebaugh, 2007).

In his seminal article, 'the tragedy of the commons', Hardin (1968) conceptualises the commons as resources for which there is free and unmanaged access. He argues that this unregulated access would inevitably culminate in resource depletion and environmental degradation because humans are naturally competitive economic creatures (homo economicus) that would try to maximise their revenue and thereby not take care of these common resources (as there is no incentive to do so) and eventually plunder them. The policy implications of this approach are clear: the most "rational" way to sustain the commons is either through private or state-led governance.

Viewed as 'the intellectual rehabilitation of the commons' (De Angelis and Harvie, 2013: 284), the works of Ostrom $(1990,2002,2010)$ elegantly show that Hardin's "tragedy" is far from inevitable. Ostrom finds that the commons involve communities that negotiate 
the modalities of access to these resources. These communities engage in a form of selfmanagement that effectively arranges the 'collective allocation of common resources and user's responsibilities' (Fournier, 2013: 448). This organisation enables the sustainability of the commons and the related communities for centuries. In a nutshell, Ostrom's works are essential to recognise that many communities can organise in the common to manage the allocation of common resources and responsibilities between users.

However, some scholars argue that despite its strength, Ostrom's analysis does not go far enough (Caffentizis, 2004; De Angelis and Harvie, 2013; Fournier, 2013; Hardt and Negri, 2009). In Ostrom's cases, what comes after the allocation of common resources is private ownership (e.g. one can sell the allocated resource to make money). De Angelis (2004), Fournier (2013), Bollier and Helfrich (2012a, 2012b) show that for many communities, the process of commoning includes not only organising in the common (i.e. the democratic and sustainable allocation of resources) but also organising for and of the common, that is, the collective and democratic use and (re)production of the commons, respectively. In these communities, in other words, the process of commoning does not stop once the resources and responsibilities are communally allocated. It also 'defines the modes of use and (re)production ... of these resources through democratic and horizontal forms of governance' (De Angelis and Harvie, 2013: 280).

In this framework, I think we can better understand the political meaning of rentierism, characterised by the enclosure and expropriation of the commons. Marx writes that 'what creates the capital-relation can be nothing other than the process which divorces the worker from the ownership of the conditions of his own labour' (1990: 874). Indeed, for Marx, 'the divorce of labour from her means of subsistence ... forms the concept of capital' (Bonefeld, 2011: 396). He is extremely precise on this: 'the capital-relation presupposes a complete separation between the workers and the ownership of the conditions for the realisation of their labour' (Marx, 1990: 874). This relation, according to Marx, 'evolves in such a way that it [capital] maintains and reproduces this separation on a constantly increasing scale until the historical reversal takes place' (1971: 271, emphasis added). The historical reversal Marx mentions here suggests an association between direct producers and the means of production or, more generally, workers' access to, use and (re)produce of social wealth in a mode of organisation that is not strictly mediated by the natural laws of capitalism (De Angelis, 2004). 
The commons resisting enclosures and the practices of commoning that emerge around these commons are threats to the ordinary run of things. They present themselves as a limit on the very premise of capitalist social relations: separation. The communities that produce and reproduce through the practices of commoning are not utopias. They are real antagonistic movements, showing that there can be a sustainable life beyond capital (and state) around the commons. In this regard, rentierism does indeed concern the enclosure of the commons through the mechanisms of 'accumulation by dispossession', that is, the transfer of common assets to the upper classes as a response to inner contradictions of capital accumulation, especially when surpluses of capital lie idle with no profitable industrial production outlets in sight (Harvey, 2003). However, given that every economic category is simultaneously political, rentierism should also be read as capital's political counter-movement, enforcing separation on spaces where communities organise around the commons and experiment with the practices of commoning towards inventing alternative social systems that are not determined by the priorities and drives of capital.

\section{A Concluding Remark: Reclaiming the Commons}

In this article, I have argued that rentierism or rentier capitalism rests essentially on the enclosure and expropriation of the commons, which have an ambivalent relationship with capital (De Angelis, 2013). The commons are used as the basis for capitalist growth. However, the same commons also constitute the basis for alternative autopoietic social systems that might overcome the hegemony of capital. Enclosures, in other words, define a strategic terrain among social forces. By enclosing the commons, capital attempts to fix or temporarily overcome its inner contradictions -as in rentierism. But by doing so, it simultaneously destroys 'the cell form of the social force that is responsible to establish and reproduce life, and by this to abolish capital' (De Angelis, 2013: 613, emphasis added).

In the final chapter of Rentier Capitalism, Christophers (2020: 386- 409) discusses four key areas in which some actions should be taken to move beyond rentierism. While he acknowledges these areas as i) competition policy, ii) tax system, iii) state-led formation of a new economy, and iv) ownership, he aptly puts the accent on the latter, for '[ownership] underpins all the others' (2020: 399). Indeed, 'what, after all, is rentier capitalism if not a mode of economic production and reproduction in which the bulk of 
society's valuable economic assets are owned by capital' (2020: 399). Christophers suggests that these assets should be 'retaken from rentiers' (2020: 404). But when retaken, who will own them? He offers 'a mixed, plural ecology of ownership' in which, for example, some natural resources are given to the state, intellectual properties stay in private hands, and others are transferred to some communities (2020: 407). Yet, he does not explain why, for example, intellectual properties stay in private hands (see Karakilic, 2019).

I shall conclude in a more provocative way. As various social movements across the world have been expressing for decades, neither markets nor states have been able to provide social justice, sustainability, and happy lives for all. While states cannot be abstracted from capital (e.g. 'state-finance nexus', Harvey, 2010), capital, in turn, reproduces socioeconomic injustices, asymmetrical power relations, environmental catastrophes, and depressed lives. The commons belong to their real owners, namely the commoners who can, under particular conditions, define for themselves alternative social systems that are not mediated by capital or the state. What these conditions (as well as the limits and boundaries of commoning) might be and how they can be addressed collectively might inform future research (see De Angelis and Stavrides, 2010). 


\section{Endnotes}

i Rentier Capitalism opens with an epigraph which might be regarded as the most condensed form of Christophers' overall thesis: 'the current transformation of capitalism is characterised by a fullfledged comeback and proliferation of forms of rent' (Vercellone, 2008 quoted in Christophers, 2020: iii). Carlo Vercellone, who could not find any further place in Christophers' works, was not only one of the earliest scholars (2008) theorising the return of rentierism by offering the concept of 'the becoming-rent of profit' but he was also the one who did that through Marx: 'with an extraordinary power of foresight, the development of the analysis of volume III of Capital, together with the Grundrisse, helps us see ... the becoming rent of capital was inevitable'

ii "The merchants, the rentiers as well as financiers are repositioned as the arbiters of capital accumulation relative to industrial capital. This is how the distribution of wealth and income became so distorted from the 1970s onwards' (Harvey, 2014: 160).

iii 'Industrial capitalism has given way increasingly to ... rentier capitalism, and the mechanisms by which rentier capitalism works are more and more about appropriation and accumulation by dispossession than they are about the organization of production and the exploitation of living labour in production' (Harvey, 2019: para 10). Indeed, Harvey's (2003) The New Imperialism offers many elements that explain the return of rentierism from a Marxist perspective.

iv 'At this level, capitalism supports itself on rent. The great industrialists, instead of reinvesting profit, recycle it in the mechanisms of rent. The circuit, the blood of capital, is now rent; rent plays an essential role in the circulation of capital and the maintenance of the capitalist system: it maintains social hierarchies and the command of capital' (Negri, 2018, para: 18).

v Christophers examines rentier capitalism in the UK. However, he recognises that the UK experience is broadly representative of the wider system of Western rentier capitalism' (2020: xxxvi).

vi Self-valorisation in Marx means the expanded reproduction of every element of class relations.

vii 'Our common knowledge is the foundation of all new production of knowledge; linguistic community is the basis of all linguistic innovation; ... and our common social image bank makes possible the creation of new images' (Hardt and Negri, 2004: 148). 


\section{References}

Arrighi G (1994) The Long Twentieth Century: Money, Power, and the Origins of Our Times. London: Verso.

Askenazy P (2016) Tous Rentiers! Pour une Autre Repartition des Richesses. Paris: Odile Jacob.

Bollier D and Helfrich S (eds.) (2012a) The Wealth of the Commons: A World Beyond Market and State. Amherst, MA: Levellers Press.

Bollier D and Helfrich (eds.) (2012b) Patterns of Commoning. Amherst, MA: Levellers Press.

Bonefeld W (2011) Primitive accumulation and capitalist accumulation: Notes on social constitution and expropriation. Science \& Society 75(3): 379-399.

Boutang YM (2011) Cognitive Capitalism. Cambridge: Polity

Caffentzis, G. (2004). A tale of two conferences: Globalization, neoliberalism and the question of the commons. A Talk Prepared for the Alter-Globalization Conference, San Miguel de Allende, Mexico. Available at:

http://sduk.us/silvia george david/caffentzis a tale of two conferences.pdf

Christophers B (2019) The rentierization of the United Kingdom economy. EPA: Economy and Space. Online First. Available at:

https://journals.sagepub.com/doi/abs/10.1177/0308518X19873007

Christophers B (2020) Rentier Capitalism: Who Owns the Economy and Who Pays for It? London-New York: Verso.

Cleaver H (2000) Reading Capital Politically. Texas: University of Texas Press.

De Angelis M (2001) Marx and primitive accumulation: The continuous character of capital's enclosures. The Commoner. 2 September. Available at:

https://thecommoner.org/wp-content/uploads/2019/10/Marx-and-primitiveaccumulation-deAngelis.pdf

De Angelis M (2004) Separating the doing and the deed: Capital and the continuous character of enclosures. Historical Materialism 12(2): 57-87.

De Angelis M (2013) Does capital need a commons fix? ephemera: theory and politics in organization 13(3): 603-615

De Angelis M and Harvie D (2013) The commons. In Parker M, Cheney G, Fournier V and Land C (eds.), The Routledge Companion to Alternative Organisation. London: Routledge. pp. 280-294. 
De Angelis M and Stavrides S (2010) On the commons: A public interview with Massimo de Angelis and Stavros Stavrides. e-flux 17. Available at: https://www.eflux.com/journal/17/67351/on-the-commons-a-public-interview-with-massimo-deangelis-and-stavros-stavrides/

Fournier V (2013) Commoning: On the social organisation of the commons. M@n@gement 16: 433-453.

Fuchs C (2014) Digital Labour and Karl Marx. New York-Oxon: Routledge.

Hardin G (1968) The tragedy of the commons. Science 162(3859): 1243-1248.

Hardt M (2010) The common in communism. Rethinking Marxism 22(3): 346-356.

Hardt M and Negri A (2004) Multitude: War and Democracy in the Age of Empire. New York: Penguin

Hardt M and Negri A (2009) Commonwealth. Cambridge, MA: Harvard University Press.

Harvey D (2003) The New Imperialism. Oxford: Oxford University Press.

Harvey D (2010) The Enigma of Capital and The Crisis of Capitalism. London: Profile Books.

Harvey D (2014) Seventeen Contradictions and the End of Capitalism. New York: Oxford University Press.

Harvey D (2019) Accumulation by dispossession.

Available at: https://www.democracyatwork.info/acc accumulation by dispossession

Hodkinson S (2010). Housing in common: In search of a strategy for housing alterity in England in the 21st century. In Fuller D, Jonas A and Lee R (eds.), Interrogating Alterity: Alternative Economic and Political Spaces. Farnham: Ashgate. pp. 241-258.

Holder J and Flessas T (2008) Emerging commons. Social and Legal Studies 17(3): 299310.

Karakilic E (2019) Rethinking intellectual property rights in the cognitive and digital age of capitalism: An autonomist Marxist reading. Technological Forecasting and Social Change 147: 1-9.

Linebaugh P (2007) Magna Carta Manifesto: Liberties and Commons for All. Berkeley, CA: University of California Press.

Marx K (1971) Theories of Surplus Value, v. 3. Moscow: Progress Publishers.

Marx K (1990) Capital: A Critique of Political Economy, v. 1. London: Penguin.

Marx K (1992) Capital: A Critique of Political Economy, v. 3. London: Penguin. 
Marx K (1993) Grundrisse: Foundations of the Critique of Political Economy. London: Penguin Books.

Mazzucato M (2018) The Value of Everything: Making and Taking in the Global Economy. London: Allen Lane.

Negri A (2018) Starting again from Marx. Radical Philosophy 2(03). Available at: https://www.radicalphilosophy.com/article/starting-again-from-marx

Nonini D (2006) Introduction: The global idea of the 'common'. Social Analysis 50(3):164177.

Ostrom E (1990) Governing the Commons. Cambridge: Cambridge University Press.

Ostrom E (ed.) (2002) The Drama of the Commons. Washington: National Academic Press.

Ostrom E (2010) Beyond markets and states: Polycentric governance of complex economic systems. The Nobel Prizes 2009, Stockholm: Available at: https://www.nobelprize.org/prizes/economic-sciences/2009/ostrom/lecture/

Parker M, Cheney G, Fournier V et al. (eds.) The Routledge Companion to Alternative Organization. Oxon-New York: Routledge.

Piketty T (2014) Capital in the Twenty-First Century. Cambridge, MA: The Belknap Press of Harvard University Press.

Piketty T (2020) Capital and Ideology. Cambridge, MA: Belknap Press: The Belknap Press of Harvard University Press.

Sayer A (2015) Why We Can't Afford the Rich. Bristol: Policy Press.

Shiva V (2002) Protect or Plunder? Understanding Intellectual Property Rights. London: Zen Books.

Standing G (2016) The Corruption of Capitalism: Why Rentiers Thrive and Work Does Not Pay. London: Biteback.

Tricarico A (2012) The coming financial enclosure of the commons. In: Bollier D and Helfrich S (eds.), The Wealth of the Commons: A World Beyond Market and State. Amherst, MA: Levellers Press. Available at: http://wealthofthecommons.org/essay/comingfinancial-enclosure-commons

Tronti M (1966) Operai e Capitale. Turin: Einaudi.

Vercellone C (2008) The new articulation of wages, rent and profit in cognitive capitalism. In: A Conference on The Art of Rent, Queen Marry University. Available at: https://halshs.archives-ouvertes.fr/halshs-00265584/document 
Vercellone C (2010) The crisis of the law of value and the becoming-rent of profit. In: Fumagalli A and Mezzadra S (eds.), Crisis in the Global Economy: Financial Markets, Social Struggles, and New Political Scenarios. Los Angeles: Semiotext (e). pp. 85-119.

Zanini A (2010) On the 'philosophical foundations' of Italian workerism: A conceptual approach. Historical Materialism 18(4): 39-63. 